sity staff, most evident in the department of surgery. They moved not only to technologically developed regions and to the Middle East, where the pay is good and the facilities modern, but also to other African countries that were considered to be less developed but more stable politically and economically than Nigeria. The lack of teaching aids and equipment and a drastic reduction in foreign aid (staff exchange and supplies of books, journals, and equipment) has encouraged staff migration, as has the decline in social standing of "academics" and medical doctors and the relatively slow rise to the top in a university department of surgery.

As a result of this trend, in 1988 the faculty of medicine started recruiting medical graduates from the top $15 \%$ of their year as assistant lecturers, encouraging them to make a career in the teaching profession within the medical specialties.

In spite of all efforts, student-teacher contact time is short, and the atmosphere for research and continuing medical education and therefore for staff development is inappropriate. Many countries in tropical Africa may be going through this decadence; the future of medical education seems bleak.

Funding: None.

Conflict of interest: None.

1 Perhoff GT. Graduate medical education confronted. $\mathscr{F} A M A$ 1988;259:402-4.

Giddings AEB Organisation of general surgical service in Britain: strategic planning of work load and manpower. Br f Surg 1993;80:1377-8.

3 Steele RJC, Logie JRC, Munro A. Technical training in surgery: the trainSteele RJC, Logie JRC, Munro A. Tech
ee's view. Br f Surg 1989;76:1291-3.

4 Blamey RW, Dudley HAF. Higher degree in surgical training: a pre-meeting workshop at the Surgical Research Society. Br f Surg 1984;71:861-2.

5 Sussman L, Gupta Y. Different perspectives of inventory managemen among physicians and hospital administrations. Am $\mathcal{F}$ Surg 1992;164:1-2.

6 Ritchie WP. Academic medical centre, a stressed institution. Am $\mathcal{f}$ Surg 1989;157:538-40.

7 World Health Organisation. Intersectoral health. Geneva: WHO, 1986:45-6. 8 National Universities Commission. Course system and grade point average in Nigerian universities. Zaria: ABU Press, 1979.

9 National Postgraduate Medical College of Nigeria, Faculty of Surgery. Guidelines to candidates for the fellowship in surgery. Lagos: Urgent Printing Press, 1982.

10 West African College of Surgeons. Prospectus. Lagos: West African College of Surgeons, 1979.

(Accepted 5 December 1995)

\title{
Controversies in Management
}

\section{Screening asymptomatic people at high risk for hepatitis C}

\section{The case for}

\author{
Carol A Seymour
}

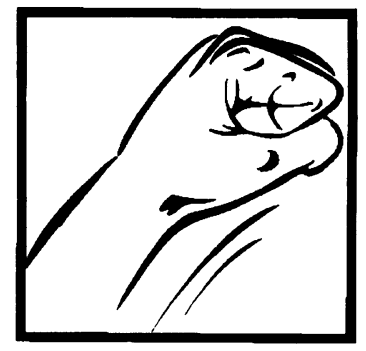

In some respects hepatitis C is hepatitis B revisited. Years after the discovery of hepatitis B virus and 11 years after development of a safe, efficacious vaccine, consensus has emerged in the international health community that decisive global action against hepatitis $\mathrm{B}$ is a necessity. ${ }^{1}$ Those who doubt that a similar approach will be needed towards hepatitis $\mathrm{C}$ point to a relative lack of knowledge of the clinical course of hepatitis $\mathrm{C}$ and the efficacy of treatment.

In 1989 hepatitis $C$ virus was cloned and characterised as a positive sense, single stranded RNA genome containing 9400 nucleotides. It is a major cause of posttransfusion hepatitis ${ }^{2}$; up to $50 \%$ of patients commonly progress to chronic hepatitis and $20 \%$ to cirrhosis with secondary complications such as hepatocellular carcinoma. ${ }^{3} \mathrm{~A}$ problem arises because hepatitis $\mathrm{C}$ may have a progressive course to chronic disease occurring over decades, during which time the individual may be symptom free and the disease remain undiagnosed until the patient presents with liver disease or its complications. ${ }^{2}$

\section{Likely size of the problem}

In the United States 3.5 million people are estimated to have chronic hepatitis $\mathrm{C}$; of these, 8000-10000 die of liver related complications and 1000 undergo liver transplantation. ${ }^{4}$ Around $23 \%$ of patients given a transplant had hepatitis C virus, and $19 \%$ of those given transplants for seronegative cryptogenic cirrhosis developed hepatitis $\mathrm{C}$ after transplantation. ${ }^{45}$ Prevalence is similar in Europe and higher in Japan and other eastern countries.

The hepatitis $\mathrm{C}$ virus is transmitted parenterally through blood, blood products, injecting drug misuse, and tattooing, as well as by sexual ${ }^{6}$ and household transmission. Serological identification of hepatitis C virus by second and third generation assays for detecting antibodies to the virus (by enzyme linked immunosorbent assay (ELISA) and recombinant immunoblot assay (RIBA)) combined with analysis of hepatitis $C$ virus RNA by polymerase chain reaction have greatly improved specific detection and diagnosis of hepatitis $\mathrm{C}$ and have predictive value. ${ }^{78}$ Hepatitis $\mathrm{C}$ virus has now been systematically classified on the basis of nucleic acid sequence analysis to six main genotypes, some associated with severe liver disease. ${ }^{9}$

Thus early diagnosis is now feasible, and it is essential if treatment is to be effective before progression to chronic hepatitis $\mathrm{C}$ and cirrhosis, when only the liver transplantation option would apply. The challenge is to decide who to screen and how, and when and why it should be done, and at what cost. These questions are difficult to answer even for of one of our commonest genetic disorders, cystic fibrosis. ${ }^{10}$ But there is some encouragement from results of the screening programme of blood donations and transfusion associated hepatitis in Britain, which have shown that between 1 in 1400 and 1 in 5000 first time blood donors have antibodies to hepatitis $\mathrm{C}$ virus, ${ }^{11}{ }^{12}$ and suggest that each year 10 000-13000 transmissions of hepatitis $C$ could be prevented by adequate screening. But what of those who do not donate blood?

\section{Advantages of early detection of hepatitis C}

There are clear advantages to targeted screening for hepatitis $\mathrm{C}$ virus in asymptomatic people at high risk. Aside from counselling about the disease, its mode of transmission, effects on the liver, and so on, identification of young people in the early stages of the disease would reach those who would benefit most from treatment with interferon alfa. Once they have been identified, counselling of such individuals is likely not only to reduce (or even prevent) further hepatitis $\mathrm{C}$ virus transmission but to allow these people to have a 
more informed choice about lifestyle and habits that can exacerbate unsuspected liver disease, such as drug ingestion and alcohol use. ${ }^{12}$ Identification of hepatitis $\mathrm{C}$ virus genotypes may also target those individuals who are likely to respond to early treatment. ${ }^{9} \mathrm{~A}$ recent study in the north east of England has shown the importance of such screening, that it is feasible, and that it provides information on the clinical course of the disease. ${ }^{13}$

\section{Screening methods}

There are now several ways of screening for hepatitis $C$ virus and chronic hepatitis $C$ which can satisfy criteria for candidate screening tests in terms of sensitivity, specificity, efficiency, and predictive value. Tests of liver function, in particular for serum alanine aminotransferase, although low cost, would miss most asymptomatic people and correlate poorly with liver histology. ${ }^{14}$ In the study by Watson et al only 13 of 104 people positive for hepatitis $C$ virus had abnormal results on liver tests. ${ }^{13}$ Currently there is no way of picking up asymptomatic individuals if they do not donate blood, but the clinical course of this disease indicates that a significant proportion will progress to cirrhosis, and it is important to note that many young people may be blood donors and injecting drug users. ${ }^{13}$

In American and European blood donors, tests for antibodies to hepatitis $C$ virus (ELISA confirmed by recombinant immunoblot assay) have detected a prevalence of $0.2-0.4 \%$, which is an underestimate of the prevalence in the general population. As indicated by the study in north east England, despite reduction in false positive results by improved assays for antibodies, false positive results may still occur and can now be resolved by detection of hepatitis $C$ virus RNA in serum by polymerase chain reaction, which is now more widely available in kits. Even this method may be complicated by intermittent viraemia, which occurs in chronic hepatitis $\mathrm{C}$, or when imperfect serum storage leads to a false negative result with the polymerase chain reaction test. ${ }^{13}$ These problems are not a good argument against screening for hepatitis C virus; rather, they argue for involvement of experts in reporting results of such tests. Where doubt exists and where liver abnormality is suspected, liver biopsy is essential. ${ }^{13}{ }^{15}$ The risks of the biopsy procedure have been greatly overemphasised; the procedure is not risky provided that it is carried out by liver specialists, who are now available in most if not all hospitals. Hepatitis $\mathrm{C}$ virus RNA can also be detected in liver biopsy tissue.

\section{Effectiveness of current treatment}

The past decade has established that interferon alfa is the sole treatment for chronic hepatitis C. ${ }^{4}{ }^{16}$ Critics may note that some studies indicate that only $25 \%$ of patients currently treated for 6-12 months sustain complete remission (with eradication of the virus ${ }^{17}$ ); high doses or combination regimens (including ribavirin) may improve on this. Two recent studies looking at the long term response to the treatment were more encouraging. ${ }^{18} 19$

Once identified by screening tests, people affected by hepatitis $\mathrm{C}$ can be selected for treatment on the basis of genotypic, biochemical, viral, and histological markers. There is increasing evidence that early treatment of asymptomatic and young people ${ }^{1318}{ }^{19}$ may prevent progression to chronic hepatitis $\mathrm{C}$ and cirrhosis. Large scale trials are now required to assess long term treatment, and a screening programme for asymptomatic hepatitis $C$ would identify those suitable for these studies.

There is no doubt that early identification and treatment of appropriate asymptomatic people at high risk has implications both for those people and for health care allocation of resources. Recent cost assessments show that in the United States there are 1000 liver transplants for hepatitis C a year. ${ }^{4}$ Studies of cost effectiveness in terms of lives saved per year are encouraging. It has been suggested that around $\$ 71950$ was saved in non-cirrhotic patients with chronic hepatitis $C$ treated with interferon, and a life year gained in cirrhotic patients cost $\$ 33230 .^{20}$

\section{Conclusion}

Screening of high risk individuals for hepatitis $\mathrm{C}$ both in hospitals and in the community is possible and has clear benefits for the individuals, their families, and society. Molecular technology now permits identification of hepatitis $\mathrm{C}$ virus genotypes, which are more informative about the disease and the likely response to treatment. In time (as for hepatitis B) such technology will inevitably produce vaccines.

Current use of interferon alfa is effective in the short term, but there is doubt about its efficacy in the long term, and clinical trials of alternative regimens and combination therapy are needed. But how should we identify the patients if not by screening? It is now more than ever timely to have a targeted screening programme for asymptomatic people at high risk of hepatitis $\mathrm{C}$, which will also enlarge our database for answering some of the outstanding questions about hepatitis $\mathrm{C}$ and its management. Remember hepatitis $\mathrm{B}$ ?

1 Moradpour D, Wands JR. Understanding Hepatitis B infection [editorial] N Engl f Med 1995;332:1092-3.

2 Van der Poel CL, Cuypers HT, Reesink HW. Hepatitis C virus six years on Lancet 1994;344:1475-9.

3 Alter HJ. Epidemiology of hepatitis C in the West. Semin Liver Dis 1995;15:5-14.

4 Terrault $\mathrm{N}$, Wright T. Interferon and hepatitis C. $N$ Engl $f$ Med 1995;332:1509-11.

5 Ascher NL, Lake RJ, Emond J, Roberts J. Liver transplantation for hepatitis C virus-related cirrhosis. Hepatology 1994;20:245-275.

6 Bresters D, Mauser-Bunschoten EP, Reesink HW, Roosendale G, van der Bresters D, Mauser-Bunschoten EP, Reesink HW, Roosendale G, van
Poel CL. Sexual transmission of hepatitis C. Lancet 1993;342:210-1.

7 Uyttendaele S, Claeys H, Mertens W, Verhaert H, Vermylen C. Evaluation of third-generation screening and confirmatory assays for HCV antibodies. Vox Sang 1994; 6:122-9.

8 Zaaijer HL, Cuypers HT, Reesink HW, Winkel IN, Gerken G, Lelie PN. Reliability of polymerase chain reaction for detection of hepatitis $C$ virus. Lancet 1993;341:722-4.

9 Dusheiko G, Schmilovitz-Weiss H, Brown D, McOmish F, Yap P-L, Sherlock $S$, et al. Hepatitis $C$ virus genotypes: an investigation of type-specific differences in geographic origin and disease. Hepatology 1994;19:13-8.

10 Cuckle HS, Richardson GA, Sheldon TA, Quirke P. Cost effectiveness of antenatal screening for cystic fibrosis. BMF 1995;311:1460-3.

11 Goodrick MJ, Gray SF, Rouse AM, Waters AJ, Anderson NA. Hepatitis C (HCV) positive blood donors in south-west England: case control study. (HCV) positive blood donors
Transfusion Med 1994;4:113-9.

12 Maclennan S, Moore MC, Hewitt PE, Nicoles S, Barbara JAJ. A study of anti-hepatitis $C$ positive blood donors: the first year of screening. Transfusion Med 1994;4:130-3.

13 Watson JP, Brind AM, Chapman CE, Bates CL, Gould FK, Johnson SJ, et al. Hepatitis $C$ virus: epidemiology and genotypes in the north east of England. Gut 1996;38:269-276.

14 Bruno S, Rossi S, Petroni ML, Villa E, Zuin M, Podda M. Normal aminotransferase concentration in patients with antibodies to hepatitis $C$ virus. $B M F$ 1994;308:697.

15 Seymour CA. Asymptomatic infection with hepatitis $C$ virus [editorial] BMF 1994;308:670-1.

16 Tine F, Magrin S, Craxi A, Pagliaro L. Interferon for non-A non-B chronic hepatitis: a meta-analysis of randomised clinical trials. $f$ Hepatol 1991;13:192-9.

17 Saracco G, Rossina F, Abate ML, Carucci P, Solinas A, Chianduss L, et al. Long term follow-up of patients with chronic hepatitis $C$ treated with different doses of interferon-alpha 2b. Hepatology 1993;18:1300-5.

18 Tong MJ, El-Farra NS, Reikes AR, Co RL. Clinical outcomes after Tong MJ, El-Farra NS, Reikes AR, Co RL. Clinical outcomes after
transfusion-associated hepatitis C virus infection. $N$ Engl $f \mathrm{Med}$ transfusion-associated

19 Polynard T, Bedossa P, Chevallier M, Mathurin P, Lemonnier C, Trepo C, et al. A comparison of three interferon alfa-2b regimens for the long term treatment of chronic non-A non-B hepatitis. $N$ Engl $f$ Med 1995;332:1457-62.

20 Shiell A, Briggs A, Farrell GC. The cost effectiveness of alpha interferon in the treatment of chronic active hepatitis C. Med $\mathcal{F}$ Aust 1994;160:268-72.

(Accepted 13 February 1996) 